\title{
EVALUASI KINERJA PEMELIHARAAN ASET BANGUNAN PABRIK BLOK A - 06 DI PT. KAWASAN BERIKAT NUSANTARA (PERSERO)
}

\author{
Pasya Faishal Aushoof, Nurlaila Fadjarwati, Mariah Rabiatul Qibtiyah \\ Prodi Manajemen Aset, Jurusan Administrasi Niaga, Politeknik Negeri Bandung \\ Penulis Korespondensi e-mail: pasyafaishal@gmail.com
}

\begin{abstract}
PT. Kawasan Berikat Nusantara (Persero) owns the building assets of block factory A-06 with an area of $5,400 \mathrm{~m}^{2}$ with the condition of the building does not undergo improvement (indcondition) so that the offer price is low and the cost of repair of the building is high. There is also a waiting time when repairs are made so that investors need to wait for repairs to be completed. In the know of the performance of asset maintenance in the building of Block factory A - 06 used Key Maintenance Performance Indicators (Muchiri, 2010) based on 2 working areas (dimensions) are Leading Indicators and Lagging Indicators. The method used in the study is a descriptive method with a quantitative approach through data collection techniques for both interviews and documentation studies. The result of maintenance performance evaluation of the building assets of block plant A - 06 is known that the maintenance has been done is not optimal. A recommendation to solve the problem is to make a replanning of the $A-06$ block factory building asset maintenance system.

Keywords: evaluation of asset maintenance performance, building asset, building, Key Maintenance

Performance Indicators.
\end{abstract}

\begin{abstract}
Abstrak
PT. Kawasan Berikat Nusantara (Persero) memiliki aset bangunan pabrik blok A - 06 dengan luas $5.400 \mathrm{~m}^{2}$ dengan kondisi bangunan tidak mengalami perbaikan (indcondition) sehingga harga penawaran sewanya rendah dan biaya perbaikan bangunannya tinggi. Terdapat juga waktu tunggu saat perbaikan dilakukan sehingga investor perlu menunggu perbaikan diselesaikan. Dalam mengetahui kinerja pemeliharaan aset pada bangunan pabrik blok A - 06 digunakan Key Maintenance Performance Indicators (Muchiri, 2010) berdasarkan 2 area kerja (dimensi) yaitu Leading Indicators dan Lagging Indicators. Metode yang digunakan dalam penelitian yakni metode deskriptif dengan pendekatan kuantitatif melalui teknik pengumpulan data baik wawancara dan studi dokumentasi. Hasil evaluasi kinerja pemeliharaan aset bangunan pabrik blok A 06 diketahui bahwa pemeliharaan yang telah dilakukan tidak optimal. Rekomendasi pemecahan masalahnya adalah dibuat perencanaan ulang sistem pemeliharaan aset bangunan pabrik blok A - 06.

Kata Kunci : evaluasi kinerja pemeliharaan aset, aset bangunan, Key Maintenance Performance Indicators.
\end{abstract}




\section{PENDAHULUAN}

Prospek kawasan industri mengalami kenaikan tiap tahun, faktor yang mendorong lonjakan penjualan lahan industri disebabkan adanya kenaikan arus investasi asing langsung di Indonesia. Berdasarkan data Badan Koordinasi Penanaman Modal (BKPM) Triwulan I Tahun 2019, Penanaman Modal Asing (PMA) dalam sektor industri tumbuh 4.9 \% menjadi Rp 107,9 triliun, sedangkan Penanaman Modal Dalam Negeri (PMDN) naik 8.9\% menjadi Rp 195.1 triliun. Dalam laporan Badan Koordinasi Penanaman Modal menunjukkan bahwa realisasi investasi PMDN dan PMA dari tahun 2014 hingga triwulan I 2019 mengalami kenaikan. Gambar 1 menunjukkan grafik perkembangan realisasi investasi dalam sektor industri tahun 2014 sampai 2019.

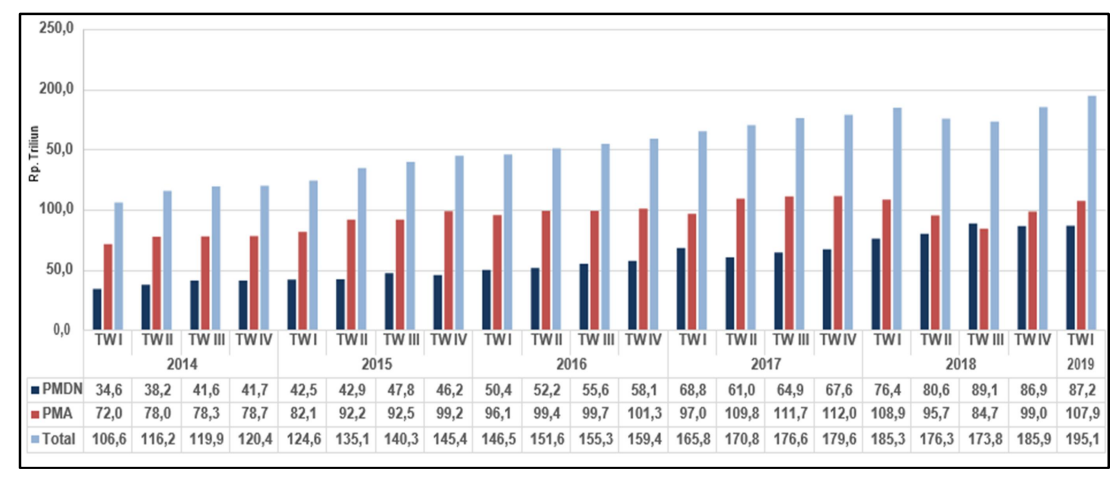

Gambar 1. Grafik perkembangan realisasi investasi 2014 - kwartal I 2019 Sumber : Badan Koordinasi Penanaman Modal, 2019

Grafik di atas menunjukkan bahwa realisasi investasi di Indonesia dalam 5 tahun terakhir mengalami kenaikan. Untuk mengakomodasi permintaan industri yang terus naik akibat realisasi investasi yang kian membaik, pemerintah melakukan upaya dalam memfasilitasi kegiatan pengelola kawasan berikat yang menyediakan lokasi industri melalui PT. Kawasan Berikat Nusantara (Persero). Penyediaan kawasan berikat milik BUMN dapat menjadi alternatif bagi calon investor mencari lokasi yang tepat untuk kegiatan industri dalam kawasan industri terpadu berstatus berikat.

PT. Kawasan Berikat Nusantara (Persero) memiliki aset fisik berupa bangunan pabrik, gudang tertutup, gudang terbuka, dan kendaraan pengangkut. Pendapatan terbesar dari kegiatan usaha utama PT. Kawasan Berikat Nusantara (Persero) diperoleh melalui penyewaan bangunan pabrik. Tabel 1 menunjukkan realisasi pendapatan operasional tahun 2018 . 
Tabel 1. Realisasi pendapatan operasional tahun 2018

PT. Kawasan Berikat Nusantara (Persero) (Dalam miliar rupiah)

\begin{tabular}{|l|c|c|}
\hline \multicolumn{1}{|c|}{ Unit Bisnis Stategis } & Kegiatan Usaha Utama & $\mathbf{2 0 1 8}$ \\
\hline Strategic Business Unit (SBU) Kawasan Cakung & Sewa Bangunan Pabrik & 138,79 \\
\hline \multirow{2}{*}{$\begin{array}{l}\text { Strategic Business Unit (SBU) Pelayanan } \\
\text { Logistik }\end{array}$} & Jasa Pergudangan & 75,94 \\
\cline { 2 - 3 } & $\begin{array}{c}\text { Jasa Angkutan, Jasa Mekanik, dan } \\
\text { Dokumen }\end{array}$ & 8,10 \\
\hline Strategic Business Unit (SBU) Pengelolaan Air & Pengelolaan Air Kawasan & 38,44 \\
\hline Strategic Business Unit (SBU) Prima Beton & Produksi Beton & 55,56 \\
\hline \multirow{2}{*}{ Manajemen Operasi } & $\begin{array}{c}\text { Jasa Pelayanan Kesehatan dan } \\
\text { Kebersihan }\end{array}$ & 28,31 \\
\hline
\end{tabular}

Sumber : Annual Report PT. Kawasan Berikat Nusantara (2018)

Berdasarkan hasil wawancara dengan staff Bagian Pemeliharaan Kawasan diketahui bahwa perbaikan bangunan membutuhkan biaya yang besar ketika ada permintaan dari calon investor saat akan menyewa dan investor yang memberi surat permohonan perbaikan ke PT. Kawasan Berikat Nusantara (Persero). Bangunan yang dijadikan sebagai objek penelitian adalah bangunan pabrik blok A-06 dengan spesifikasi luas bangunan $5.400 \mathrm{~m}^{2}$. Bangunan tersebut merupakan bangunan yang tidak mengalami perubahan apapun atau perbaikan (Incondition) dan memiliki harga sewa sebesar Rp. 27.200/ $\mathrm{m}^{2} / \mathrm{bulan}$. Pada bulan September tahun 2019 Blok A - 06 telah di perbaiki atas permohonan investor dengan biaya perbaikan sebesar Rp. 167.300.000.

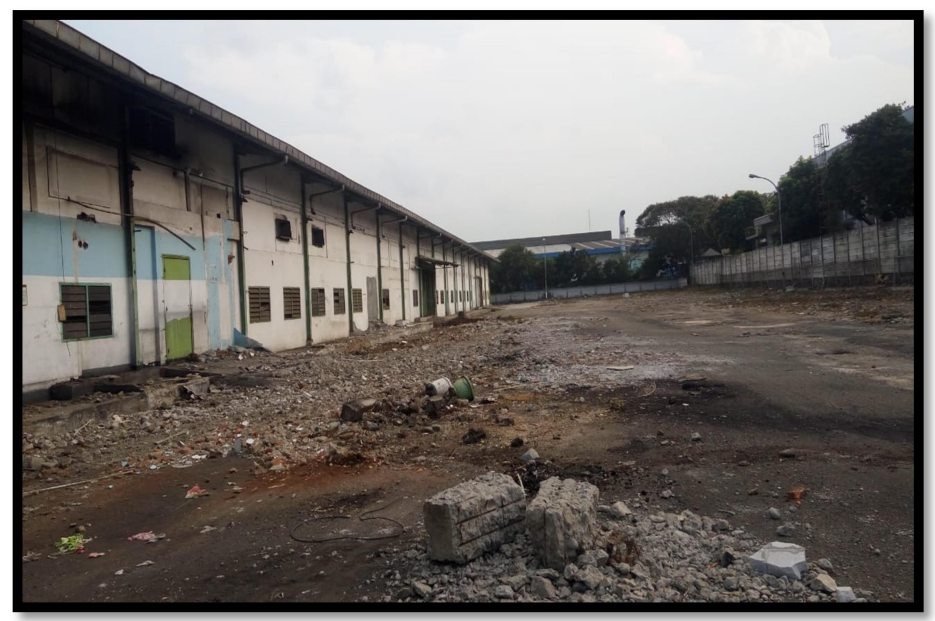

Gambar 2. Bangunan incondition pabrik A - 06 tampak samping Sumber: Peneliti, 2019

Gambar 2 menunjukkan bagian bangunan incondition blok A - 06 yang terlihat dari tampak samping masih terdapat banyak puing - puing bangunan yang terkelupas dari struktur bangunan inti. Tindakan perbaikan dilakukan untuk mengembalikan fungsi bangunan sesuai spesifikasi bangunan. Selama itu juga investor tidak dapat memuat barang 
dan mesin produksi ke dalam bangunan pabrik blok $\mathrm{A}-06$. Berbeda hal nya dengan harga sewa bangunan pabrik baru yang memiliki luas yang sama namun harga sewa yang sepakati lebih besar yaitu sebesar Rp. $31.300 / \mathrm{m}^{2} /$ bulan.

Luas bangunan pabrik yang tersedia di PT. Kawasan Berikat Nusantara (Persero) terdapat 3 jenis yaitu $1.440 \mathrm{~m}^{2}, 2.700 \mathrm{~m}^{2}$, dan $5.400 \mathrm{~m}^{2}$. Sedangkan bangunan gudang blok A - 06 merupakan luasan gudang yang terbesar. Berdasarkan uraian pada latar belakang diatas, adapun identifikasi masalah yang terdapat pada penelitian ini yaitu :

1. Bangunan yang tidak mengalami perubahan apapun atau perbaikan (In-condition) memiliki harga penawaran sewa yang rendah

2. Memiliki potensi perbaikan bangunan atas permintaan investor yang memerlukan biaya yang lebih besar dikemudian hari

3. Terdapat waktu tunggu saat perbaikan bangunan pabrik dilakukan, sehingga investor perlu menunggu hingga perbaikan diselesaikan

Berdasarkan identifikasi masalah di atas, kegiatan pemeliharaan yang telah diterapkan oleh PT. Kawasan Berikat Nusantara (Persero) perlu di evaluasi. Kinerja pemeliharaan aset dapat dievaluasi menggunakan Key Maintenance Performance Indicators (Muchiri, 2010) yang meliputi dua dimensi yaitu leading indicators dan lagging indicators yang terdiri dari enam indikator yaitu work identification. work planning \& scheduling, work execution, equioment effectiveness, maintenance cost effectiveness, safety and environment. Teori tersebut digunakan dalam penelitian ini karena dapat diimplementasikan dalam proses pemeliharaan di banyak sektor industri. Mengevaluasi dengan Key Maintenance Performance Indicators mampu mengukur aspek penting dari dimensi leading indicators dan lagging indicators. Penelitian ini berfokus pada proses pemeliharaan dan hasil pemeliharaan yang telah diterapkan pada bangunan pabrik blok A - 06. Penjelasan tersebut menunjukkan pentingnya kinerja pemeliharaan pada bangunan pabrik blok A - 06 dalam memengaruhi kemampuan organisasi untuk memberikan layanan yang berkualitas dan tepat waktu kepada investor dan menjadi yang terdepan dalam persaingan.

\section{TINJAUAN PUSTAKA}

\section{A. Pemeliharaan Aset}

Menurut Peters (2015), pemeliharaan aset merupakan aktivitas yang dilakukan untuk memastikan dan memulihkan ke kondisi yang dapat diterima untuk memenuhi standar 
fungsionalnya. Aktivitas pemeliharaan mencakup aktivitas korektif dan preventif seperti penyimpanan peralatan, servis, pengujian, inspeksi, penyesuaian, pemindahan, penggantian, instal ulang, pemecahan masalah, kalibrasi, penentuan kondisi, perbaikan, modifikasi, pemeriksaan, pembangunan kembali dan reklamasi.

Sedangkan menurut Peraturan Menteri Pekerjaan Umum Nomor 24/PRT/M/2008 Tentang Pedoman Pemeliharaan dan Perawatan Bangunan Gedung, pemeliharaan bangunan gedung adalah kegiatan menjaga keandalan bangunan gedung beserta prasarana dan sarananya agar bangunan gedung selalu layak fungsi. Pemeliharaan aset ini menjadi salah satu faktor penting dalam menjaga kualitas produk yang dihasilkan, karena itu pemeliharaan aset dapat dijadikan sebagai pendukung perangkat dalam bersain.

Sudrajat (2011) mengemukakan bahwa tujuan pemeliharaan aset sebagai berikut:

1) Menjamin ketersediaan, keandalan fasilitas secara ekonomis maupun teknis, sehingga dalam penggunaannya dapat dilaksanakan secara optimal.

2) Memperpanjang umur ekonomis fasilitas.

3) Menjamin kesiapan operasional fasilitas yang diperlukan dalam keadaan darurat.

4) Menjamin keselamatan kerja dan keamanan dalam penggunaannya.

Pemeliharaan merupakan bagian dari kegiatan pendukung bagi kegiatan komersil, maka seperti kegiatan lainnya, pemeliharaan harus efektif, efesien dan ekonomis. Dengan diaplikasikan aktivitas pemeliharaan, maka aset dapat digunakan sesuai dengan rencana dan tidak mengalami kerusakan selama jangka waktu tertentu.

\section{B. Jenis Pemeliharaan Aset}

Menurut Sofjan Assauri (2004) mengklasifikasikan jenis - jenis Jenis pemeliharaan kedalam dua jenis, yaitu preventive maintenance dan corrective maintenance. Sedangkan menurut Mobley (2004) jenis pemeliharaan dibagi menjadi 3 jenis yaitu improvement, preventive dan corrective. Ketiga jenis pemeliharaan tersebut memiliki perbedaan dilihat dari waktu dan kondisi dalam merancang sistem pemeliharaan sebagai berikut:

\section{1) Improvement Maintenance}

Pemeliharaan perbaikan merupakan upaya untuk mengurangi atau menghilangkan kebutuhan akan perawatan. Upaya rekayasa keandalan harus menekankan penghapusan kegagalan langsung pada sumbernya. Pemeliharaan perbaikan adalah aktivitas untuk melakukan tindakan dari pada bereaksi atas suatu kerusakan (Mobley, 2004)

\section{2) Preventive Maintenance}

pemeliharaan pencegahan melibatkan pelaksanaan pemeriksaan rutin dan servis yang 
menjaga fasilitas - fasilitas dalam kondisi baik. Pemeliharaan pencegahan bertujuan untuk membangun sistem yang mengetahui kerusakan potensial dan membuat penggantian atau perbaikan yang aan mencegah kerusakan (Heizer \& Rander, 2006).

\section{3) Corrective Maintenance}

Pemeliharaan korektif merupakan kegiatan pemeliharaan yang dilakukan setelah terjadinya kerusakan atau terjadi kelainan pada fasilitas dan peralatan sehingga tidak dapat berfungsi dengan baik (Tampubolon, 2004).

\section{Evaluasi Kinerja Pemeliharaan Aset}

Menurut Wirawan (2012), evaluasi adalah riset untuk mengumpulkan, menganalisis, dan menyajikan informasi yang bermanfaat mengenai suatu objek, untuk dinilai dan dibandingkan dengan indikator sehingga hasilnya dipergunakan untuk mengambil keputusan mengeni objek evaluasi tersebut.

Menurut Gomes (dalam Rodseth, 2017) alasan utama adanya Key Maintenance Performance Indicator di suatu organisasi adalah untuk mengontrol dan meningkatkan fungsi perawatan. Hal tersebut menjadi bagian penting dari manajemen pemeliharaan untuk pengukuran evaluasi kinerja. Berdasarkan pendapat tersebut dapat diartikan bahwa mengukur kinerja merupakan hal yang penting dalam pemeliharaan karena dapat memastikan dan memverifikasi bahwa kegiatan pemeliharaan yang direncanakan dan dilaksanakan telah memberikan hasil yang diharapkan.

Definisi Key Maintenance Performance Indicator yang dijelaskan oleh Muchiri (2010) bahwa key maintenance performance indicators adalah dasar untuk manajemen pemeliharaan, salah satu masalah utama adalah untuk memastikan kegiatan pemeliharaan yang direncanakan dan dilaksanakan telah memberikan hasil yang diharapkan. Muchiri (2010) juga mengemukakan bahwa Key Maintenance Performance Indicators memiliki dua dimensi yang penting dalam pengelolaan fungsi pemeliharaan yaitu Maintenance Process/ Effort Indicators (Leading Indicators) dan Maintenance Result Indicators (Lagging Indicators). Dalam tiap dimensi terdapat 3 indikator yang mendukung pemantauan dan pengendalian kinerja pemeliharaan, serta membantu mengidentifikasi tindakan pemeliharaan terhadap tujuan pemeliharaan.

Penggunaan data yang akan dianalisis oleh Key Maintenance Performance Indicators meliputi data aktivitas pemeliharaan preventif dan pemeliharaan korektif. Jika salah satu aktivitas pemeliharaan tidak dilakukan, maka penganalisisan setiap indikator dapat 
menggunakan data salah satu pemeliharaan yang telah dilakukan. Menurut Muchiri (2011) leading indicators merupakan salah satu dimensi dari Key Maintenance Performance Indicators yang mengukur suatu pekerjaan pemeliharaan yang sedang berlangsung baik bersifat pekerjaan yang proaktif maupun reaktif diselesaikan tepat waktu sesuai dengan jadwal yang ditentukan, agar hasil produksi yang diinginkan dapat tercapai. Berikut ini merupakan penjelasan tiga indikator dari dimensi leading indicators yaitu Work Identification, Work Planning and Scheduling, dan Work Execution. Penjelasan dari ketiga indikator dijelaskan sebagai berikut :

\section{1) Work Identification}

Mengindentifikasi pekerjaan yang tepat untuk dilakukan di waktu yang tepat oleh staf pemeliharaan berdasarkan tujuan pemeliharaan. Indicator ini mengidentifikasi dan mengontrol kegagalan yang mempengaruhi kemampuan aset untuk melakukan fungsi yang dimaksudkan di dalam kinerja yang diperlukan. Aktivitas dievaluasi berdasarkan konsekuensi kegagalan pada kinerja aset sehingga sumber daya pemeliharaan diarahkan untuk penggunaan yang efektif.

2) Work Planning and Scheduling

Indikator yang melakukan pekerjaan dan mengidentifikasi semua yang diperlukan sumber daya serta persyaratan khusus untuk melaksanakan pekerjaan. Perencanaan menentukan cara melakukan pekerjaan dan mengidentifikasi semua yang diperlukan sumber daya dan persyaratan khusus untuk melaksanakan pekerjaan.

\section{3) Work Execution}

Merupakan indikator yang membantu memantau efektivitas pekerjaan pemeliharaan seperti kepatuhan jadwal pekerjaan dan kualitas pekerjaan yang dilakukan dan efisiensi dari tenaga kerja dan pemanfaatan sumber daya dalam melaksanakan pekerjaan pemeliharaan. Indikator ini dapat diukur melalui persentase pekerjaan diselesaikan dalam waktu yang di jadwalkan, persentase pengerjaan ulang, persentase tugas yang diselesaikan atas semua tugas yang diterima, jumlah tugas yang terlambat dan efesiensi tenaga kerja.

Tabel 2 berikut ini merupakan rancangan pengukuran menurut Muchiri (2011) pada dimensi leading indicators guna mengetahui capaian target yang rekomendasikan. 
Tabel 2. Rancangan pengukuran leading indicators

\begin{tabular}{|c|c|c|c|c|}
\hline Indikator & Pengukuran & Satuan & Deskripsi & $\begin{array}{l}\text { Target yang } \\
\text { disarankan }\end{array}$ \\
\hline \multirow[t]{3}{*}{$\begin{array}{l}\text { Work } \\
\text { Identification }\end{array}$} & $\begin{array}{l}\text { Persentase Kerja } \\
\text { Proaktif }\end{array}$ & $\%$ & $\begin{array}{l}\text { Jam kerja yang dipertimbangkan untuk } \\
\text { pekerjaan proaktif/ total jam kerja yang } \\
\text { tersedia }\end{array}$ & $75 \%-80 \%$ \\
\hline & $\begin{array}{l}\text { Persentase Kerja } \\
\text { Reaktif }\end{array}$ & $\%$ & $\begin{array}{l}\text { Jam kerja yang dipertimbangkan untuk } \\
\text { pekerjaan reaktif/ total jam kerja yang } \\
\text { tersedia }\end{array}$ & $10 \%-15 \%$ \\
\hline & $\begin{array}{l}\text { Tingkat Respons } \\
\text { Permintaan } \\
\text { Pekerjaan }\end{array}$ & $\%$ & $\begin{array}{l}\text { Permintaan pekerjaan tersisa dalam status } \\
\text { "permintaan" selama }<5 \text { hari/ total } \\
\text { permintaan pekerja }\end{array}$ & $\begin{array}{l}80 \% \text { dari } \\
\text { permintaan }\end{array}$ \\
\hline \multirow[t]{5}{*}{$\begin{array}{l}\text { Work } \\
\text { Planning \& } \\
\text { Scheduling }\end{array}$} & $\begin{array}{l}\text { Intensitas } \\
\text { Perencanaan }\end{array}$ & $\%$ & $\begin{array}{l}\text { Pekerjaan yang direnacakan/ total } \\
\text { pekerjaan yang dilakukan }\end{array}$ & $\begin{array}{lr}>95 \% & \text { dari } \\
\text { semua } & \text { perintah } \\
\text { kerja } & \end{array}$ \\
\hline & $\begin{array}{l}\text { Kualitas } \\
\text { Perencanaan }\end{array}$ & $\%$ & $\begin{array}{lccr}\text { Persentase } & \text { perintah kerja } & \text { yang } \\
\text { membutuhkan } & \text { pengerjaan ulang } & \text { karena } \\
\text { perencanaan/ semua perintah kerja } & \end{array}$ & $\begin{array}{l}<3 \% \text { dari } \\
\text { semua perintah } \\
\text { kerja }\end{array}$ \\
\hline & $\begin{array}{l}\text { Intensistas } \\
\text { Jadwal }\end{array}$ & $\%$ & $\begin{array}{l}\text { Jam kerja terjadwal/ total jam kerja yang } \\
\text { tersedia }\end{array}$ & $\begin{array}{lr}>\quad 80 \% & \text { jam } \\
\text { kerja } & \text { yang } \\
\text { tersedia } & \end{array}$ \\
\hline & $\begin{array}{l}\text { Kualitas } \\
\text { Penjadwalan }\end{array}$ & $\%$ & $\begin{array}{l}\text { Persentase perintah kerja dengan eksekusi } \\
\text { tertunda karena material atau tenaga kerja }\end{array}$ & $<2 \%$ \\
\hline & $\begin{array}{l}\text { Tingkat Realisasi } \\
\text { Jadwal }\end{array}$ & $\%$ & $\begin{array}{l}\text { Perintah kerja dengan tanggal yang } \\
\text { dijadwalkan lebih awal atau sama dengan } \\
\text { tanggal selesai/ semua perintah kerja }\end{array}$ & $\begin{array}{l}>\quad 95 \% \text { dari } \\
\text { semua perintah } \\
\text { kerja }\end{array}$ \\
\hline \multirow[t]{3}{*}{$\begin{array}{l}\text { Work } \\
\text { Execution }\end{array}$} & $\begin{array}{l}\text { Kepatuhan } \\
\text { Jadwal }\end{array}$ & $\%$ & $\begin{array}{l}\text { Persentase perintah kerja yang diselesaikan } \\
\text { dalam periode yang dijadwalkan sebelum } \\
\text { tanggal selesai }\end{array}$ & $>90 \%$ \\
\hline & $\begin{array}{l}\text { Tingkat } \\
\text { Pemanfaatan } \\
\text { Tenaga Kerja }\end{array}$ & $\%$ & $\begin{array}{l}\text { Total jam yang dihabiskan untuk tugas/ } \\
\text { jam kerja yang tersedia }\end{array}$ & $>80 \%$ \\
\hline & $\begin{array}{l}\text { Kualitas } \\
\text { pelaksanaan } \\
\text { (pengerjaan } \\
\text { ulang) }\end{array}$ & $\%$ & $\begin{array}{l}\text { Persentase pekerjaan pemeliharaan yang } \\
\text { membutuhkan pengerjaan ulang }\end{array}$ & $<3 \%$ \\
\hline
\end{tabular}

Sumber : Modifikasi dari Muchiri (2011)

Indikator yang terkait dengan hasil pemeliharaan disebut lagging indicators, karena hasil pemeliharaan dapat diketahui jika aktivitas pemeliharaan telah diselesaikan dalam periode waktu tertentu. Hasil dari pemeliharaan dapat diringkas sebagai keandalan (Reliability), ketersediaan (Availability), pengoperasian sistem teknis (Operability of the technical systems). Ketiga hal tersebut merupakan elemen inti yang ditangani oleh pemeliharaan. Berikut ini merupakan penjelasan tiga indikator dari dimensi lagging indicators menurut Muchiri (2011) sebagai berikut :

\section{1) Equipment Effectiveness (Performance)}

Merupakan indikator yang mendukung manajemen pemeliharaan dalam mengukur ketersediaan peralatan dan tingkat perencanaannya. Dalam mengukur ketersediaan 
peralatan, elemen - elemen yang di kontrol adalah frekuensi kegagalan peralatan dan waktu perbaikan. kedua elemen tersebut menentukan waktu henti peralatan yang tidak direncanaan.

\section{2) Maintenance Cost Effectiveness}

Merupakan indikator yang dipengaruhi oleh pekerjaan pemeliharaan yang dilakukan. pemeliharaan tidak hanya untuk meminimalkan keselamatan lingkungan dan konsekuensi dari kegagalan tetapi juga untuk mengurangi biaya pemeliharaan. dapat diukur dengan melihat persentase biaya pemeliharaan terhadap penerimaan pendapatan. Jika perbaikan kerusakannya ringan, maka dibutuhkan lebih sedikit waktu untuk memperbaiki (penghematan tenaga kerja) dan mengkonsumsi lebih sedikit material (penghematan bahan). Sehingga secara keseluruhan biaya perbaikan akan berkurang.

\section{3) Safety and Environment}

Merupakan indikator yang menilai suatu kegagalan sehingga menyebabkan hilangnya fungsi atau kerusakan lain yang dapat melukai atau membunuh seseorang dan melanggar standar lingkungan.

Tabel berikut ini merupakan rancangan pengukuran menurut Muchiri (2011) pada dimensi lagging indicators guna mengetahui capaian target yang rekomendasikan. Tabel 3 menunjukkan rancangan pengukuran lagging indicators sebagai berikut.

Tabel 3. Rancangan pengukuran lagging indicator

\begin{tabular}{|c|c|c|c|c|}
\hline Indikator & Pengukuran & Satuan & Deskripsi & $\begin{array}{l}\text { Target yang } \\
\text { disarankan }\end{array}$ \\
\hline \multirow{2}{*}{$\begin{array}{l}\text { Equipment } \\
\text { effectiveness } \\
\text { (performance) }\end{array}$} & $\begin{array}{l}\text { Mean Time Between Failures } \\
\text { (MTBF) }\end{array}$ & $\%$ & $\begin{array}{l}\text { Total waktu perawatan total/ } \\
\text { jumlah total perbaikan }\end{array}$ & $50 \%$ \\
\hline & $\begin{array}{l}\text { Overall Equipment } \\
\text { Effectiveness (OEE) }\end{array}$ & $\%$ & $\begin{array}{l}\text { Ketersediaan } \mathrm{x} \text { Tingkat } \\
\text { Kinerja x Tingkat Kualitas }\end{array}$ & $85 \%$ \\
\hline \multirow[t]{2}{*}{$\begin{array}{l}\text { Maintenance } \\
\text { Cost } \\
\text { Effectiveness }\end{array}$} & $\begin{array}{lr}\text { Biaya } & \text { Pemeliharaan } \\
\text { dibandingkan } \\
\text { penjualan }\end{array} \quad \begin{array}{l}\text { pendapatan } \\
\end{array}$ & $\%$ & $\begin{array}{l}\text { Biaya pemeliharaan/ total } \\
\text { penjualan }\end{array}$ & $6-8 \%$ \\
\hline & $\begin{array}{l}\text { Biaya Perawatan Melibihi } \\
\text { Biaya Produksi }\end{array}$ & $\%$ & $\begin{array}{l}\text { Biaya pemeliharaan/ biaya } \\
\text { produksi }\end{array}$ & $<10-15 \%$ \\
\hline $\begin{array}{l}\text { Safety \& } \\
\text { environment }\end{array}$ & $\begin{array}{l}\text { Jumlah insiden keselamatan, } \\
\text { kesehatan dam balik }\end{array}$ & No. & Jumbah insiden & $\begin{array}{l}\text { Konteks } \\
\text { khusus }\end{array}$ \\
\hline
\end{tabular}

Sumber : Modifikasi dari Muchiri (2011)

\section{METODE PENELITIAN}

Objek pada penelitian ini adalah bangunan yang disewakan untuk digunakan sebagai bangunan pabrik dan merupakan luasan bangunan pabrik yang terbesar dengan memiliki luas $5.400 \mathrm{~m}^{2}$. Objek penelitian terletak di blok A - 06 di zona berikat PT. Kawasan Berikat Nusantara (Persero) Kawasan Cakung. Metode penelitian yang digunakan adalah 
metode deskriptif dengan pendekatan kuantitatif. Metode penelitian deskriptif merupakan jenis penelitian yang bertujuan mendeskripsikan secara sistematis, faktual, dan akurat mengenai fakta dan sifat populasi tertentu, atau mencoba menggambarkan fenomena secara detail (Yusuf, 2014).

Teknik pengumpulan data yang digunakan adalah wawancara dan studi dokumentasi. Populasi yang digunakan dalam penelitian ini adalah Bagian Pemeliharaan Kawasan yang terdiri dari tiga divisi yaitu divisi pemeliharaan, pengelolaan kawasan, dan manajemen operasional. Dalam menentukan sample maka digunakan purposive sampling yang terdiri dari tiga staff dan satu supervisor divisi pemeliharaan kawasan.

Divisi Pemeliharaan Kawasan dipilih sebagai sampel karena mengetahui segala kegiatan pemeliharaan bangunan, sarana prasarana, dan utilitas kawasan, sehingga data yang diperlukan dalam penelitian ini dapat diperoleh di Divisi Pemeliharaan Kawasan. Teknik analisis data kuantitatif menurut Sugiyono (2017) terdapat statistik parametris dan nonparametris. Penelitian ini menggunakan teknik analisis statistik nonparametris dengan pengujian binomial. Test uji binomial digunakan untuk menguji hipotesis bila dalam populasi terdiri atas dua kelompok klas, datanya berbentuk nominal, dan jumlah sampelnya kurang dari 25 (Sugiyono, 2017).

Jika dalam suatu populasi dengan jumlah $\mathrm{N}$, terdapat satu kelas berkategori $\mathrm{x}$, maka kategori yang lain adalah $\mathrm{N}-\mathrm{x}$. Probabilitas memperoleh $\mathrm{x}$ objek dalam satu kategori dan $\mathrm{N}-\mathrm{x}$ dalam kategori lain adalah :

$$
P^{(x)}=\left(\begin{array}{l}
N \\
x
\end{array}\right) P^{x} Q^{N-x}
$$

Dimana $\mathrm{P}$ adalah proporsi kasus yang dihrapkan dalam salah satu kategori, dan $\mathrm{Q}$ adalah kategori lainnya, besarnya Q adalah 1 - P. Untuk menghitung $\left(\begin{array}{l}N \\ X\end{array}\right)$ dapat dihitung dengan rumus sebagai berikut :

$$
\left(\begin{array}{l}
N \\
X
\end{array}\right)=\frac{N !}{X !(N-X) !}
$$

Pengujian binomial bertujuan untuk menguji perbedaan antara frekuensi observasi melalui indikator yang diukur dari key maintenance performance indicators dengan frekuensi yang diharapkan yaitu recommended target untuk setiap indikator yang diukur. 


\section{HASIL DAN PEMBAHASAN}

Berdasarkan identifikasi masalah yang ada pada bangunan pabrik blok A - 06 maka dihasilkan evaluasi kinerja pemeliharaan aset bangunan blok A - 06 di PT. Kawasan Berikat Nusantara (Persero) dengan menggunakan Key Maintenance Performance Indicators yang terdiri dari dua dimensi yaitu Leading Indicators dan Lagging Indicators. Dari masing - masing dimensi memiliki tiga indikator dalam menilai kinerja pemeliharaan yang diterapkan di PT. Kawasan Berikat Nusantara (Persero). Berikut hasil evaluasi dari keenam indikator tersebut.

\section{A. EVALUASI DIMENSI LEADING INDICATORS}

Berdasarkan hasil wawancara kepada tiga staff dan satu supervisor Divisi Pemeliharaan Kawasan serta studi dokumentasi pada memorandum pekerjaan pemeliharaan untuk mengukur ketiga indikator yakni Work Identification, Work Planning \& Scheduling, dan Work Execution. . Pengukuran ketiga indikator tersebut dapat dilihat sebagai berikut:

\section{1) Work Identification}

a) Persentase Kerja Proaktif

$$
0 / 160 \times 100 \%=0 \%
$$

$0=$ Total jam kerja pekerjaan proaktif dalam pekerjaan pemeliharaan bangunan pabrik blok A - 06 tidak dilakukan.

$160=$ Total waktu kerja selama satu bulan dengan rincian delapan jam kerja per hari dalam lima hari kerja.

$100 \%=$ Persentase

Berdasarkan perhitungan di atas, dapat diketahui bahwa persentase kerja proaktif tidak terpenuhi sesuai target yang direkomendasikan sebesar $75 \%-80 \%$.

b) Persentase Kerja Reaktif

$$
80 / 160 \times 100 \%=50 \%
$$

$80=$ Total jam kerja pekerjaan reaktif dalam pekerjaan pemeliharaan bangunan pabrik blok A - 06 tidak dilakukan.

160 = Total waktu kerja selama satu bulan dengan rincian delapan jam kerja per hari dalam lima hari kerja.

\section{$100 \%=$ Persentase}

Dapat diketahui bahwa persentase kerja reaktif lebih tinggi dan tidak terpenuhi sesuai target yang direkomendasikan sebesar $10 \%-15 \%$. 
c) Tingkat Respon Permintaan Pekerjaan

$$
6 / 6 \times 100 \%=100 \%
$$

$6=$ Permohonan perbaikan item pekerjaan.

$6=$ Permohonan perbaikan item pekerjaan yang ditinjau, divalidasi, dan disetujui

Pekerjaannya kurang dari 5 hari hari kerja.

$100 \%=$ Persentase

Berdasarkan perhitungan di atas, dapat diketahui pengukuran tingkat respon permintaan perkerjaan terpenuhi sesuai target yang direkomendasikan sebesar $80 \%$ dari permintaan pekerjaan.

\section{2) Work Planning \& Scheduling}

a) Intensitas Perencanaan

$$
6 / 6 \times 100 \%=100 \%
$$

$6=$ Permohonan perbaikan item pekerjaan.

$6=$ Permohonan perbaikan item pekerjaan yang dikerjakan

$100 \%=$ Persentase

Dapat diketahui bahwa persentase intensitas perencanaan terpenuhi sesuai target yang direkomendasikan sebesar $>95 \%$ dari semua perintah kerja.

b) Kualitas Perencanaan

$$
0 / 6 \times 100 \%=0 \%
$$

$0=$ Tidak terdapat pekerjaan ulang.

$6=$ Item perbaikan pekerjaan yang dilakukan pekerjaannya.

$100 \%=$ Persentase

Berdasarkan perhitungan di atas, dapat diketahui pengukuran kualitas perencanaan terpenuhi sesuai target yang direkomendasikan sebesar $<3 \%$.

c) Intensitas Jadwal

$$
80 / 160 \times 100 \%=50 \%
$$

$80=$ Total waktu kerja yang diselesaikan dalam waktu sepuluh hari dengan delapan jam kerja per harinya.

$160=$ Total waktu kerja selama satu bulan dengan rincian delapan jam kerja per hari dalam lima hari kerja.

$100 \%=$ Persentase

Dapat diketahui bahwa persentase intensitas jadwal tidak terpenuhi sesuai target 
yang direkomendasikan sebesar $>80 \%$ jam kerja yang tersedia.

d) Kualitas Penjadwalan

Bahan baku material yang digunakan dalam pekerjaan perbaikan tidak mengalami kendala karena material yang dibutuhkan dapat diperoleh di gudang bahan baku atau di toko material yang telah bermitra sebelumnya. Dapat diketahui bahwa bahan material dan tenaga kerja memiliki persentase sebesar $0 \%$, sehingga persentase kualitas penjadwalan terpenuhi sesuai target yang direkomendasikan sebesar $<2 \%$

e) Tingkat Realisasi Jadwal

$$
6 / 6 \times 100 \%=100 \%
$$

$6=$ Item perbaikan pekerjaan yang dilakukan pekerjaannya.

$6=$ Total item perbaikan yang diselesaikan dalam kurun waktu sepuluh hari

$100 \%=$ Persentase

Berdasarkan perhitungan di atas, dapat diketahui pengukuran tingkat realisasi jadwal terpenuhi sesuai target yang direkomendasikan sebesar $>95 \%$ dari semua perintah kerja

\section{3) Work Execution}

a) Kepatuhan Jadwal

$$
8 / 10 \times 100 \%=80 \%
$$

$8=$ Total hari pekerjaan diselesaikan.

$10=$ Total hari pekerjaan yang direncakanan selesai

$100 \%=$ Persentase

Dari perhitungan di atas dapat diketahui persentase pengukuran kepatuhan jadwal tidak terpenuhi sesuai target yang direkomendasikan sebesar $>90 \%$

b) Tingkat Pemanfaatan Tenaga Kerja

$$
64 / 80 \times 100 \%=80 \%
$$

$64=$ Total jam pekerjaan diselesaikan.

$80=$ Total jam pekerjaan yang direncakanan selesai

$100 \%=$ Persentase

Dari perhitungan di atas dapat diketahui persentase tingkat emanfaatan tenaga kerja tidak terpenuhi sesuai target yang direkomendasikan sebesar $>80 \%$

c) Kualitas Pelaksanaan (pekerjaan ulang)

Aktivitas perbaikan pada bangunan pabrik A - 06 tidak mengalami pekerjaan ulang karena dari segi material, tenaga kerja tidak ada kendala, sehingga persentase kualitas pelaksanaan $0 \%$, sehingga persentase kualitas pelaksanaan terpenuhi sesuai target yang 
direkomendasikan sebesar $<3 \%$.

\section{B. EVALUASI DIMENSI LAGGING INDICATORS}

Setelah leading indicator di evaluasi, selanjutnya diperlukan juga evaluasi pada dimensi lagging indicators guna mengukur kinerja pemeliharaan aset pada bangunan pabrik A - 06 menggunakan Key Maintenance Performance Indicators. Data yang diperoleh melalui wawancara dan studi dokumentasi selanjutnya digunakan untuk mengukur ketiga indicator yang terdiri dari Equipment Effectiveness (Performance), Maintenance Cost Effectiviness (Performance), dan Safety \& Enviroment. Pengukuran ketiga indikator tersebut dapat dilihat sebagai berikut:

\section{1) Equipment Effectiveness (Performance)}

a) Mean Time Between Failure (MTBF)

PT. Kawasan Berikat Nusantara (Persero) hanya fokus memelihara aset bangunan yang disewakan, tidak sampai mengurusi peralatan yang ada dalam bangunan pabrik tersebut. tanggung jawab peralatan penunjang kegiatan manufaktur sepenuhnya tanggung jawab investor sebagai pengguna barang. Maka persentase yang diperoleh untuk mengukur persentase dari MTBF sebesar 0\%, sehingga persentase Mean Time Between Failure tidak terpenuhi sesuai target yang direkomendasikan sebesar 50\%.

b) Overall Equipment Effectiveness (OEE)

Sama halnya seperti MTBF bahwa PT. Kawasan Berikat Nusantara (Persero) tidak bertanggung jawab mengenai proses manufaktur yang terganggu akibat kerusakan mesin milik investor. maka tidak diperoleh data untuk mengukur OEE, dengan demikian persentase untuk overall equipment effectiveness sebesar $0 \%$, sehingga persentase Overall Equipment Effectiveness tidak terpenuhi sesuai target yang direkomendasikan sebesar $85 \%$.

\section{2) Maintenance Cost Effectiveness}

a) Biaya Pemeliharaan Melebihi Pendapatan Biaya

$$
167.300 .000 .000 / 1.762 .560 .000 \times 100 \%=9,4 \%
$$

Rp. 167.300.000 = Biaya Pemeliharaan.

Rp. 1.762.560.000 = Pendapatan sewa

$100 \% \quad=$ Persentase 
Berdasarkan perhitungan di atas, dapat diketahui biaya pemeliharaan dibandingkan dengan pendapatan biaya terpenuhi sesuai target yang direkomendasikan sebesar $6 \%$ $8 \%$.

b) Biaya Pemeliharaan Melebihi Biaya Produksi

PT. Kawasan Berikat Nusantara (Persero) hanya memperbaiki bangunan pabrik blok A - 06 yang semula bangunan incondition, pekerjaan perbaikan yang dilakukan adalah bentuk aktivitas pemeliharaan korektif atas permintaan investor, sehingga tidak diperoleh data produksi untuk mengukur persentase biaya pemeliharaan melebihi biaya produksi. dengan demikian persentase untuk biaya pemeliharaan melebihi biaya produksi tidak terpenuhi sesuai terget yang direkomendasikan sebesar $<10 \%-15 \%$.

\section{3) Safety \& Environment}

a) Jumlah Insiden Keselamatan dan Kesehatan

Selama pekerjaan perbaikan berlangsung hingga selesai, tidak terdapat satu insiden kecelakaan kerja satu pun. Hal tersebut sejalan dengan Peraturan Pemerintah Nomor 50 Tahun 2012 Tentang Penerapan Sistem Manajemen Keselamatan dan Kesehatan Kerja bahwa Sistem Manajemen Keselamatan dan Kesehatan Kerja (SMK3) bertujuan untuk mencegah, mengurangi, dan mengembangkan langkah langkah yang selamat untuk meniadakan kecelakaan. Berdasarkan tidak adanya insiden yang terjadi maka persentase jumlah insiden keselamatan dan kesehatan sebesar $0 \%$. Pengukuran ini terpenuhi sesuai dengan penuturan yang menyebutkan bahwa kecelakaan dalam bentuk apapun sebisa mungkin tidak terjadi dan sejalan dengan pasal 2 PP nomor 50 tahun 2012.

Hasil evaluasi pengukuran pada dimensi leading indicators dan dimensi lagging indicators dengan indikator yang terdiri dari work identification, work planning \& scheduling, work execution, equipment effectiveness (performance), maintenance cost effectiviness (performance), dan safety \& enviroment. Diketahui bahwa diperoleh hasil yang ditunjukan pada tabel 4. sebagai berikut:

Tabel 4. Hasil pengukuran dimensi lagging indicators

\begin{tabular}{|c|c|c|c|c|}
\hline Indikator & Pengukuran & Hasil & Target & Keterangan \\
\hline \multicolumn{5}{|c|}{ Leading Indicators } \\
\hline \multirow{3}{*}{$\begin{array}{l}\text { Work } \\
\text { Identification }\end{array}$} & Persentase Kerja Proaktif & $0 \%$ & $75 \%-80 \%$ & Tidak terpenuhi \\
\hline & Persentase Kerja Reaktif & $50 \%$ & $10 \%-15 \%$ & Tidak terpenuhi \\
\hline & $\begin{array}{l}\text { Tingkat Respons Permintaan } \\
\text { Pekerjaan }\end{array}$ & $100 \%$ & $>80 \%$ dari permintaan & Terpenuhi \\
\hline
\end{tabular}


Vol 25 No 1 Tahun 2020

\begin{tabular}{|c|c|c|c|c|}
\hline Indikator & Pengukuran & Hasil & Target & Keterangan \\
\hline \multirow{5}{*}{$\begin{array}{l}\text { Work } \\
\text { Planning \& } \\
\text { Scheduling }\end{array}$} & Intensitas Perencanaan & $100 \%$ & $>95 \%$ dari semua perintah kerja & Terpenuhi \\
\hline & Kualitas Perencanaan & $0 \%$ & $<3 \%$ dari semua perintah kerja & Terpenuhi \\
\hline & Intensistas Jadwal & $50 \%$ & $>80 \%$ jam kerja yang tersedia & Tidak terpenuhi \\
\hline & Kualitas Penjadwalan & $0 \%$ & $<2 \%$ & Terpenuhi \\
\hline & Tingkat Realisasi Tinggi & $100 \%$ & $>95 \%$ dari semua perintah kerja & Terpenuhi \\
\hline \multirow{3}{*}{$\begin{array}{l}\text { Work } \\
\text { Execution }\end{array}$} & Kepatuhan Jadwal & $80 \%$ & $>90 \%$ & Tidak terpenuhi \\
\hline & $\begin{array}{l}\text { Tingkat Pemanfaatan Tenaga } \\
\text { Kerja }\end{array}$ & $80 \%$ & $>80 \%$ & $\begin{array}{c}\text { Tidak } \\
\text { Terpenuhi }\end{array}$ \\
\hline & $\begin{array}{l}\text { Kualitas pelaksanaan } \\
\text { (pengerjaan ulang) }\end{array}$ & $0 \%$ & $<3 \%$ & Terpenuhi \\
\hline \multicolumn{5}{|c|}{ Lagging Indicators } \\
\hline \multirow{2}{*}{$\begin{array}{l}\text { Equipment } \\
\text { effectiveness } \\
\text { (performance) }\end{array}$} & $\begin{array}{l}\text { Mean Time } \\
\text { Failures (MTBF) }\end{array}$ & $0 \%$ & $50 \%$ & Tidak Sesuai \\
\hline & $\begin{array}{l}\text { Overall Equipment } \\
\text { Effectiveness (OEE) }\end{array}$ & $0 \%$ & $85 \%$ & Tidak Sesuai \\
\hline \multirow[t]{2}{*}{$\begin{array}{l}\text { Maintenance } \\
\text { Cost } \\
\text { Effectiveness }\end{array}$} & $\begin{array}{lr}\text { Biaya } & \text { Pemeliharaan } \\
\text { dibandingkan } & \text { pendapatan } \\
\text { penjualan } & \\
\end{array}$ & $9,4 \%$ & $6-8 \%$ & Tidak Sesuai \\
\hline & $\begin{array}{l}\text { Biaya Perawatan Melibihi } \\
\text { Biaya Produksi }\end{array}$ & $0 \%$ & $<10-15 \%$ & Tidak Sesuai \\
\hline $\begin{array}{l}\text { Safety \& } \\
\text { environment }\end{array}$ & $\begin{array}{l}\text { Jumlah insiden keselamatan, } \\
\text { kesehatan dam balik }\end{array}$ & $0 \%$ & Konteks khusus & Sesuai \\
\hline
\end{tabular}

Sumber: Penulis, 2019

\section{UJI BINOMIAL}

Setelah dimensi leading indicator dan lagging indicator di evaluasi, selanjutnya data hasil evaluasi akan di uji melalui tes uji binomial. Hasil evaluasi dapat dilihat pada tabel 5 sebagai berikut:

Tabel 5. Hasil evaluasi tiap dimensi

\begin{tabular}{|l|c|c|}
\hline \multicolumn{1}{|c|}{ Aspek yang diukur } & $\begin{array}{c}\text { Recommended } \\
\text { Target }\end{array}$ & $\begin{array}{c}\text { Unrecommended } \\
\text { Target }\end{array}$ \\
\hline Dimensi leading indicator & 6 & 5 \\
\hline Dimensi lagging indicator & 1 & 4 \\
\hline Total & 7 & 9 \\
\hline
\end{tabular}

Sumber: Penulis, 2019

Diketahui hasil evaluasi menunjukkan bahwa dari 16 aspek yang diukur, 9 aspek merupakan yang tidak sesuai dengan standar yang ditentukan. Untuk membuktikan hipotesis bahwa kinerja pemeliharaan yang telah dilakukan pada bangunan pabrik blok A 6 belum optimal .

1) Hipotesis yang diajukan

Ho : Kinerja Pemeliharaan aset bangunan blok A - 06 belum optimal

Ha : Kinerja pemeliharaan aset bangunan blok A - 06 sudah optimal

$\mathrm{H}^{\circ}$ :ditolak jika koefisien binomial $\leq$ alpha $(\alpha)$

$\mathrm{H} \circ$ : tidak dapat ditolak jika koefisien binomial > alpha $(\alpha)$ 
$\alpha: 5 \%$

2) Hasil Penelitian

Data hasil penelitian ditunjukan pada tabel 6 sebagai berikut:

Tabel 6. Hasil evaluasi aspek yang diukur dari tiap dimensi

\begin{tabular}{|l|c|}
\hline \multicolumn{1}{|c|}{ Alternatif Target } & Aspek Pengukuran \\
\hline Recommended Target & 7 \\
\hline Unrecommended Target & 9 \\
\hline Total & 16 \\
\hline
\end{tabular}

Sumber: Penulis, 2019

\section{3) Teknik Statistik Untuk Pengujian Hipotesis}

Dalam pengujian ini jumlah sampel independen $(\mathrm{N})=16$, dan aspek terkecilnya $(\mathrm{k})=$ 7. Berdasarkan tabel 3.2 dengan $\mathrm{N}=16, \mathrm{k}=7$ maka koefisien binomialnya $=0,402$. Dengan taraf kesalahan $\alpha$ ditetapkan $5 \%$ yang berarti $=0,05$. Maka harga $\mathrm{P}$ sebesar 0,402 ternyata lebih besar dari $0,05(0,402>0,05)$. Karena $\mathrm{P}>$ harga $\alpha$ maka Ho diterima dan Ha ditolak. Berdasarkan hasil pengukuran indikator dan pengujian hipotesis binomial, maka dapat disimpulkan definisi masalah penelitian ini adalah "Pemeliharaan Aset Bangunan Pabrik Blok A - 06 belum optimal, bahkan masih terdapat aspek pengukuran indikator yang belum memenuhi target yang direkomendasikan".

\section{KESIMPULAN DAN SARAN}

\section{A. KESIMPULAN}

Berdasarkan hasil pembahasan yang telah dijelaskan pada bab sebelumnya, maka dapat ditarik kesimpulan kinerja pemeliharaan aset berdasarkan dua dimensi yang diukur adalah sebagai berikut:

1) Bangunan pabrik blok $\mathrm{A}-06$ tidak mengalami perubahan apapun atau perbaikan (incondition) karena pemeliharaan prefentif tidak dijalankan serta persentase pemeliharaan korektif lebih tinggi dari target yang direkomendasikan. Hal tersebut menyebabkan harga sewa yang ditawarkan menjadi lebih murah dibandingkan bangunan pabrik baru dengan spesifikasi dan luasan yang sama.

2) Tingginya biaya pemeliharaan yang disebabkan oleh besarnya biaya pemeliharaan korektif untuk enam item pekerjaan pemeliharaan tidak sebanding dengan pendapatan bangunan pabrik A - 06 yang berstatus incondition. Serta tingkat pemanfaatan tenaga kerja yang masih rendah akibat tidak adanya pembagian pekerjaan yang jelas bagi para 
pekerja harian lepas.

Kesimpulan tersebut menunjukkan bahwa kinerja pemeliharaan aset bangunan pabrik A - 06 belum optimal.

\section{B. SARAN}

Berdasarkan kesimpulan di atas, saran yang diberikan adalah sebagai berikut:

1) Dibutuhkan pembagian jadwal pemeliharaan prefentif yang tepat bagi bangunan incondition dengan alokasi waktu pemeliharaan yang jelas pada setiap bangunan khususnya pada bangunan pabrik blok A - 06 .

2) Diperlukan perencanaan ulang sistem pemeliharaan yang mengakomodasi pemeliharaan preventif dan korektif agar kedepannya setiap kegiatan pemeliharaan yang direncanakan dapat dilakukan dengan memberikan hasil yang diharapkan.

\section{DAFTAR PUSTAKA}

Assauri, Sofjan. (2004). Manajemen Produksi dan Operasi. Lembaga Penerbit Fakultas Ekonomi Universitas Indonesia.

Heizer, J \& Render, B. (2006). Manajemen Operasi. Edisi 7. Jakarta: Salemba Empat.

Mobley, Keith R. (2004), Maintenance Fundamental, 2nd ed, Elsevier, Burlington.

Muchiri, P. N, Pintelon L., Martin H., \& De Meyer A.M. (2010). Empirical Analysis of Maintenance Performance Measurement in Belgian Industries. International Journal of Production Research, Vol 48, No 20, 5905-5924.

Muchiri, P, Pintelon L., Martin H., \& Gelders L,. (2011). Development of Maintenance Function Performance Measurement Fraework and Indicators. Int. J. Production Economics 131, 295 - 302.

Peraturan Menteri Pekerjaan Umum No. 24/PRT/M/2008 Tentang Pedoman Pemeliharaan Dan Perawatan Bangunan Gedung.

Peraturan Pemerintah Nomor 50 Tahun 2012 Tentang Penerapan Sistem Manajemen Keselamatan dan Kesehatan Kerja.

Peters, Ralph W. (2015). Reliable Maintenance Planning, Estimating, and Scheduling. Gulf Professional Publishing.

Rødseth, Harald. (2017). Development of Indicators for Maintenance Management within Integrated Planning. [Doctoral Theses] NTNU, 2017 : 277.

Sudrajat, Ating. (2011). Pedoman Praktis Manajemen Perawatan Mesin Industri. Bandung: PT. Refika Aditama.

Sugiyono. (2017). Metode Penelitian Bisnis Pendidikan Pendekatan Kuantitatif, Kualitatif, Kombinasi, dan R\&D. Bandung: Alfabeta.

Tampubolon, Manahan P. (2004). Manajemen Operasional. Jakarta: Ghalia Indonesia.

Wirawan. (2012). Evaluasi: Teori, Modul, Standar, Aplikasi, dan Profesi. Depok: PT. Raja Grafindo Persada 